\title{
Ambiances
}

anbiances Environnement sensible, architecture et espace urbain Varia | 2017

\section{The Orange Feeling. Mood and Atmosphere at Roskilde Festival}

The Orange Feeling. Humeur et atmosphère au Festival Roskilde

Hans Kiib, Gitte Marling and Line Marie Bruun Jespersen

\section{OpenEdition}

\section{Journals}

Electronic version

URL: http://journals.openedition.org/ambiances/829

DOI: 10.4000/ambiances.829

ISSN: 2266-839X

\section{Publisher:}

Direction Générale des Patrimoines - DAPA - MCC, UMR 1563 - Ambiances Architectures Urbanités (AAU)

\section{Electronic reference}

Hans Kiib, Gitte Marling and Line Marie Bruun Jespersen, «The Orange Feeling. Mood and Atmosphere at Roskilde Festival », Ambiances [Online], Varia, Online since 20 February 2017 connection on 19 April 2019. URL : http://journals.openedition.org/ambiances/829 ; D0I : 10.4000/ ambiances.829

This text was automatically generated on 19 April 2019

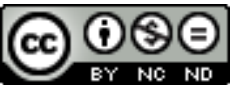

Ambiances is licensed under a Creative Commons Attribution-NonCommercial-NoDerivatives 4.0 International License. 


\section{The Orange Feeling. Mood and Atmosphere at Roskilde Festival}

The Orange Feeling. Humeur et atmosphère au Festival Roskilde

Hans Kiib, Gitte Marling and Line Marie Bruun Jespersen

The project has been generously supported by Realdania and Aalborg University.

\section{Overture}

1 A young man comes up to the mirror façade of the art installation Pose/Expose. The weather is very hot, but he wears long trousers, a T-shirt and a headband. His reflection in the mirror façade of the pavilion catches his attention, and he moves very close to the mirror to check out his looks; how is his hair? How dirty and grimy does he look after several days in bright sun, covered in a combination of sunscreen, sweat and dust? After a short glance in the mirror he quickly turns around, almost in a jump, and raises both arms in a wave to his friends. He switches quickly from the introverted, private situation in front of the mirror back to the party with his friends, who stand on the grass not far away. At the same time, inside the pavilion two girls are dancing. They are wearing wireless headphones, and dance slowly around. They drink water and look very hot, so the slow dance in the indoor environment seems to be a welcome break from the sun. The man outside draws their attention and they move very close to the window. They stand right behind him, but he cannot see them. He is concerned with his own reflection. The girls giggle, and continue dancing (observations, July 2010). 
Illustration 1: Pose/Expose, 2010, exterior

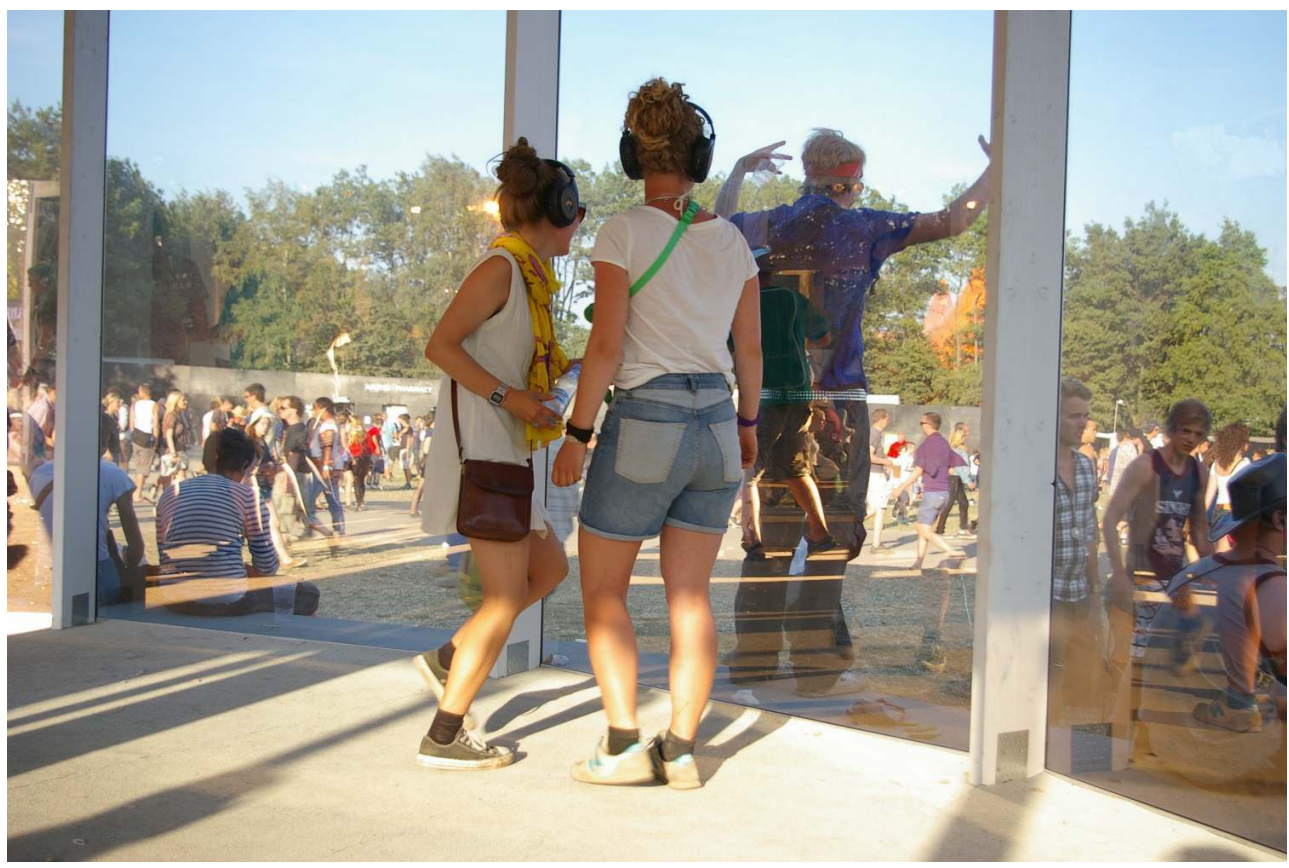

DURING THE DAY THE DANCE FLOOR IN THE PAVILION WORKS AS A STAgE, FROM WHICH THE DANCERS CAN OBSERVE THE BUSY LIFE THAT gOES ON OUTSIDE. NO-ONE CAN LOOK IN AT THE DANCERS, SO AN ATMOSPHERE OF A SECRET, YET VOYEURISTIC VIEWING POSITION IS ESTABLISHED FOR THE DANCERS.

SOURCE AND COPYRIgHT: (CLINE MARIE BRUUN JESPERSEN, fIRST PUBLISHED IN (MARLINg AND KIIB, 2011), WITH THE AUTHORIZATION OF THE AUTHORS AND EDITORS.

Illustration 2: Pose/Expose, 2010, exterior

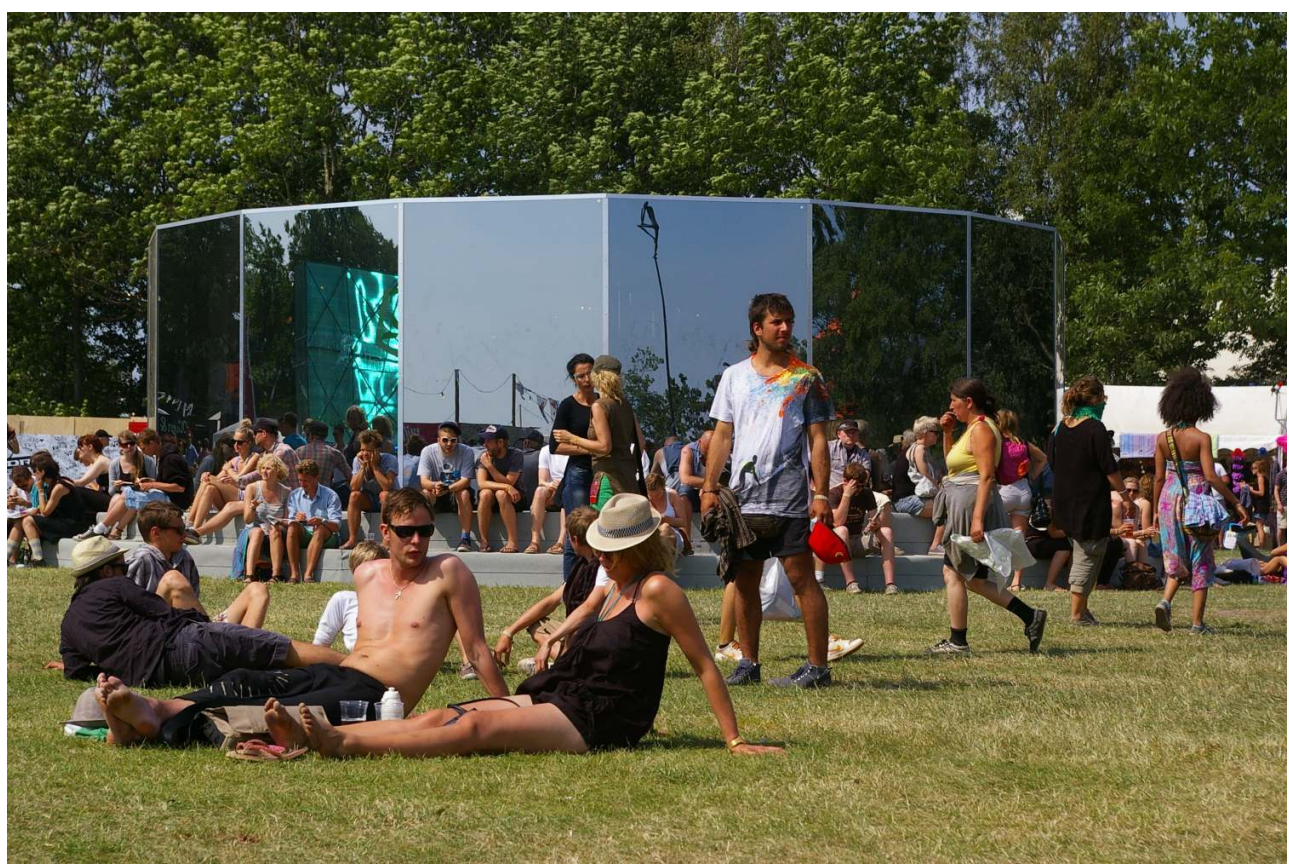

SOURCE AND COPYRIgHT: (CLINE MARIE BRUUN JESPERSEN, fIRST PUBLISHED IN (MARLING AND KIIB, 2011), WITH THE AUTHORIZATION OF THE AUTHORS AND EDITORS. 


\section{Introduction}

2 Roskilde Festival is a big, non-commercial event that has taken place every year since 1971 on an open piece of land south of Roskilde in Denmark. During the festival the whole area is transformed into the fifth largest city in Denmark - an instant city populated by approximately 120,000 people - 93,000 inhabitants, 5,000 media workers and 22,000 service employees working as volunteers in the areas of food, refuse removal and safety, etc.

3 A large part of the audience consists of young students, but the festival also attracts people in their 30s and 40s - people who have had Roskilde on their summer schedules for many years (Marling, Kiib \& Jensen, 2009, p. 153 and ff).

\section{Illustration 3: Orange stage}

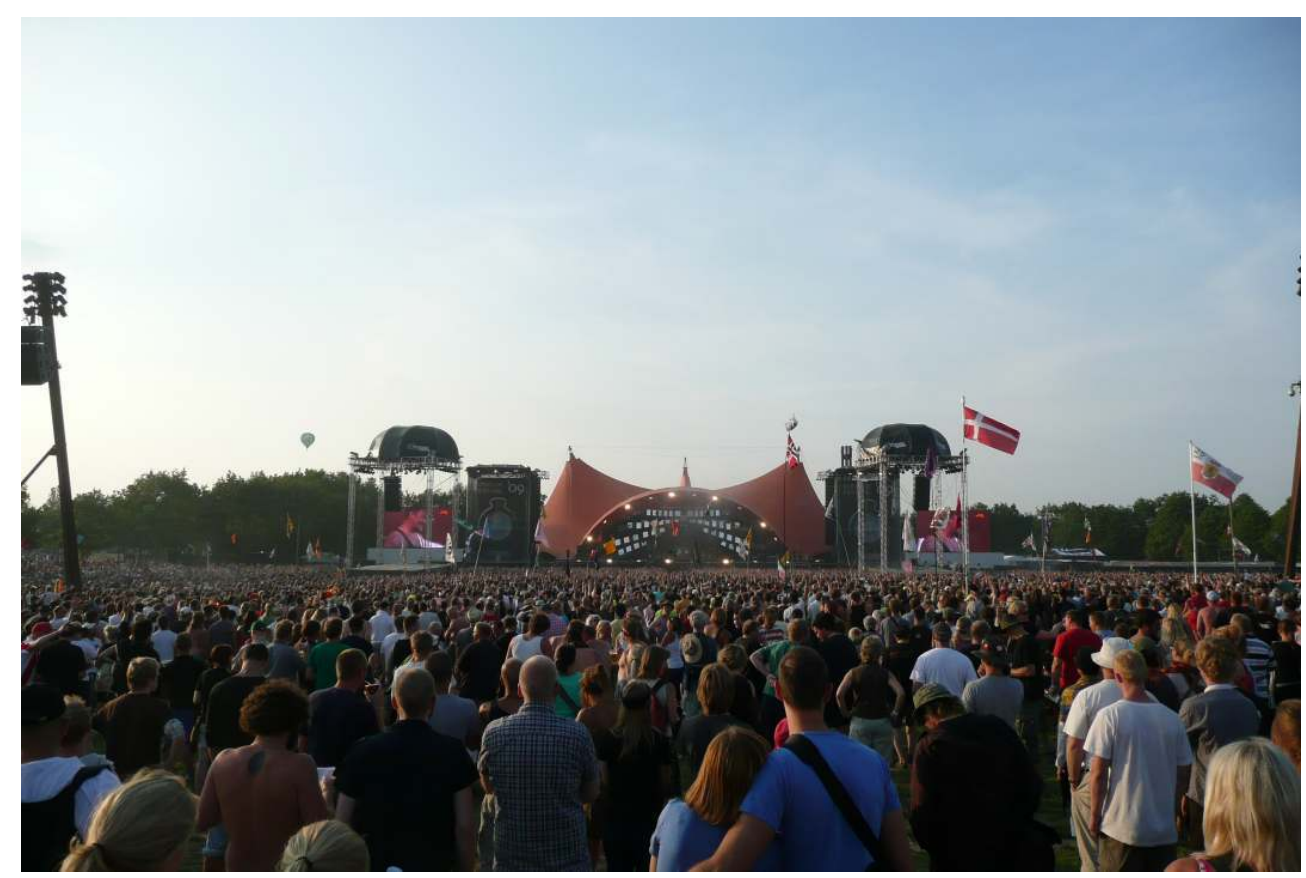

THE ICON OF THE ROSKILDE FESTIVAL IS THE ORANgE STAgE BOUgHT FROM ROLLINg STONES. IT SERVES AS A LANDMARK AND AS A NODE IN THE CITY CENTRE - IT HAS BECOME AN ICON AND HAS EVEN BEEN PICTURED ON ONE OF DENMARK'S OFfICIAL POSTAgE STAMPS

Source and copyright: (C) Gitte Marling, first published in (Marling and Kiib, 2011), with the authorization of the authors and editors.

4 The festival is organized and planned as a city, and like other cities in Denmark it has its own master plan, providing its citizens with a supply of water, electricity, wireless internet, toilets, baths and spaces for cooking, shopping, meetings, cultural activities, cafés, health care, etc.

5 But it is a temporary city, which means that all these facilities have to be established within a couple of weeks. 


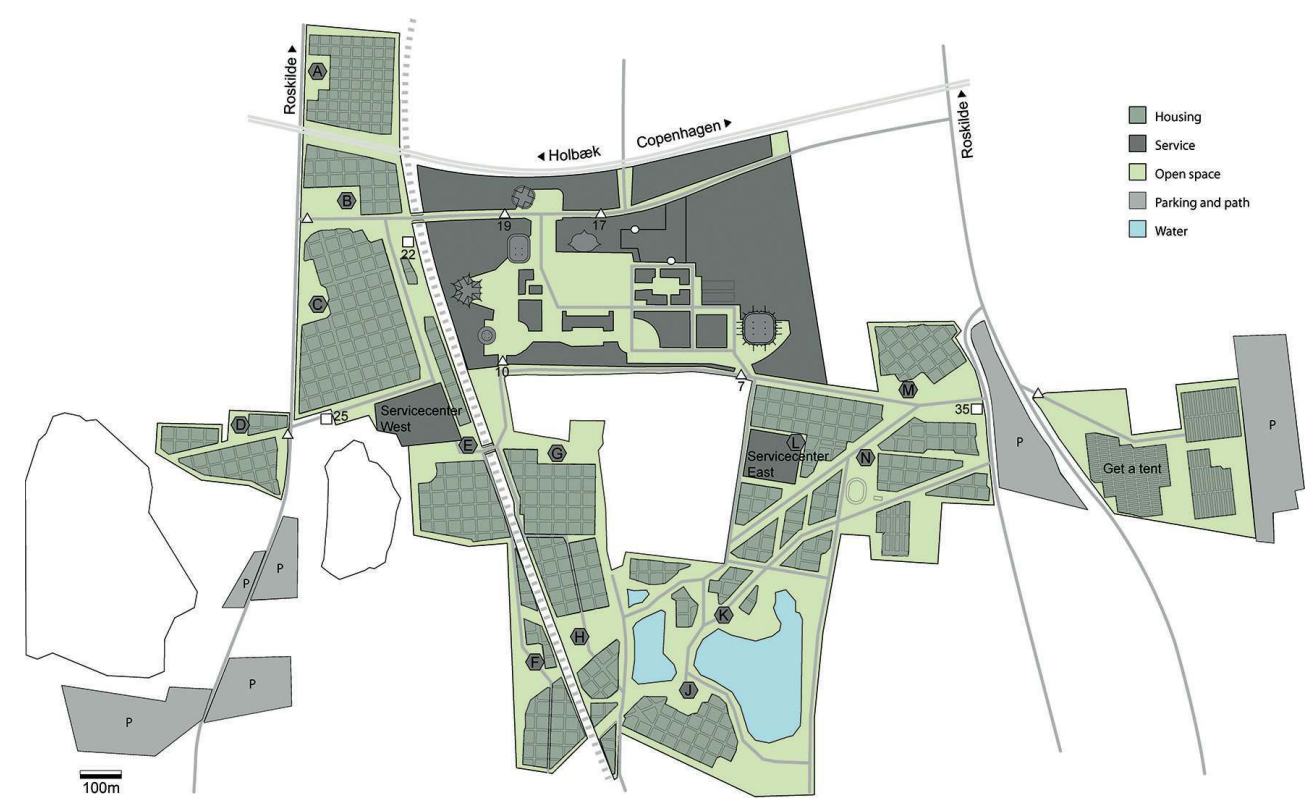

The master plan for the Roskilde Festival 2009 shows the functional layout of the city: the large stages and public spaces, shopping areas, food courts and service areas in the city centre. The tent areas have housing areas, local centres (the agoras) and two suburban centres (Centre West and Centre East). The plan is characterized by functional thinking - reminiscent of the $20^{\text {th }}$ century ideals of neighbourhoods and a structure of service centres.

Source and copyright: @ Marling \& Kiib, first published in (Marling and Kiib, 2011), with the authorization of the authors and editors.

It is interesting that a huge festival has been able to continue for more than 40 years, and year after year it has been able to gather so many people from all over the Nordic counties and many European countries too. It raises questions about which strategies the festival uses in order to renew the festival and to place itself at the cutting edge regarding music, art and performance.

7 The festival brands itself as "much more than a music festival" and underlines the construction of "space for experiences in an atmosphere of freedom and social responsibility".

This article will focus on the performative architecture and urban spaces, the relational art and the construction of situations that enhance the special mood and the atmosphere at the festival. It focuses on this phenomenon, constituted in a duality between the users and open-ended layout of possibilities, that is a dialectic between, on the one hand, space for spontaneous events and self-organized parties, and on the other hand the participants' engagement and social interactions. It is our thesis that the analysis of this may reveal some answers about The Orange Feeling.

\section{Method of the empirical research}

The site plan, the public spaces and the art installations have been analysed for all the years from 2008 to 2011. This includes registration of the city plan, the infrastructures, the programmes and the overall image of the city. The focus has been on the space, 
architectural form and the aesthetics of urban scenography and installations, and in relation to this the city life, the social interactions and self-organized events. Eight specific urban spaces have been mapped, as well as numerous tent areas.

The analyses have been presented on maps, through diagrams, photos and text (Marling and Kiib, 2011; Jespersen, 2011).

Our architectural analyses give us information about the physical context regarding the layout, the roads, the landmarks and the public spaces of the city. Furthermore they provide an image of the architectural context regarding materials, compositions of spatial elements, colours, lights, sounds and possibilities for seating etc. These architectural analyses are inspired by, amongst others, Kevin Lynch and his studies of the image of the city (Lynch, 1962); by Robert Venturi and his analyses of signs, architecture, space, streets, mobility and their relationship (Venturi et al., 1972); and by Steen E. Rasmussen's and J. Pallasmaa's work on how one experiences architecture through all the senses and through bodily interaction with the architecture (Rasmussen, 1959; Pallasmaa, 2005).

Observations in situ have provided us with definite knowledge about when and how the urban spaces, the art installations etc. are occupied and used by different user groups. Observations of users' play and interactions have provided an impression of the way they create their own space, experience and mood. We label this form of empirical research "outside in" studies.

Illustration 5: Festival public spaces

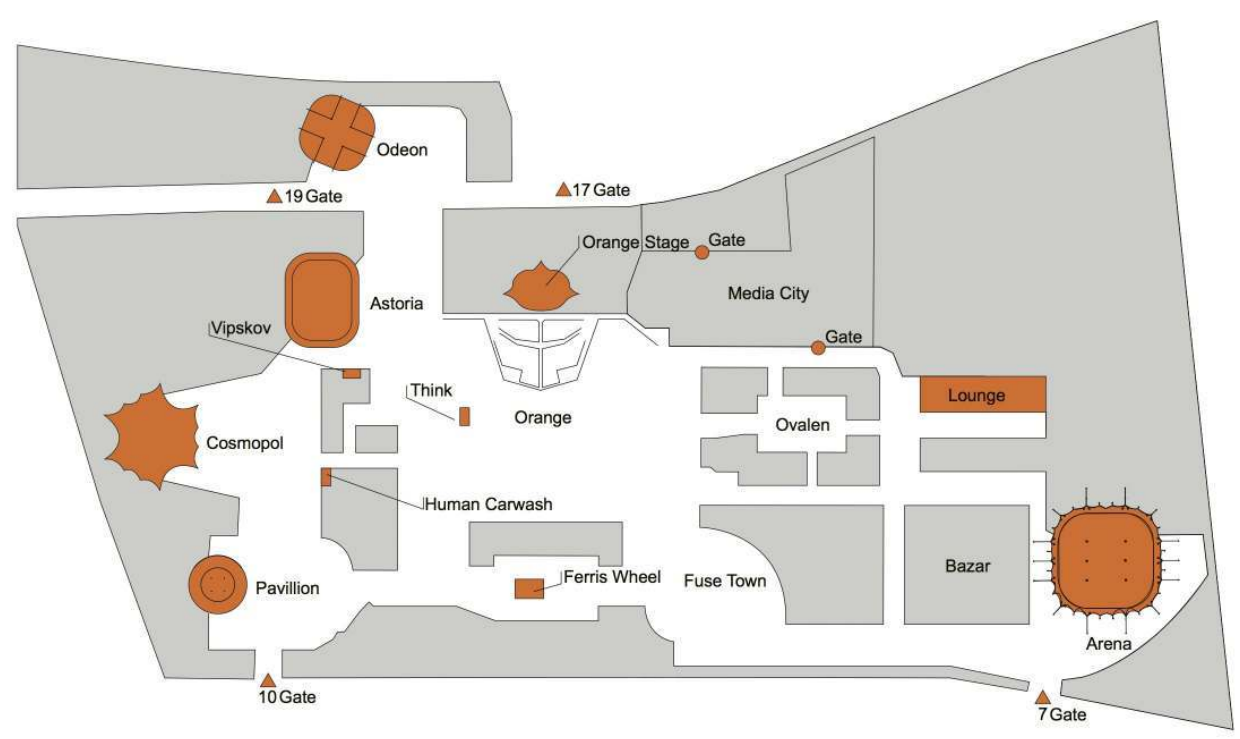

MAPPING THE MOST IMPORTANT LANDMARKS AND PUBLIC SPACES IN THE CITY CENTRE (2009). BESIDES THE 7 BIg SCENES AND THE HUgE FERRIS WHEEL, MOST RESPONDENTS ALSO POINTED OUT AREAS LIKE 'OVALEN' AND FUSE TOWN - TWO FOOD COURTS, AND THE ART INSTALLATIONS LIKE 'HUMAN CAR WASH' AND THE SCULPTURE 'THINK' IN THE BAZAAR AREA AS IMPORTANT PLACES FOR THEM. THE GREY AREAS ON THE MAP ARE BACKSTAgE AREAS -

Source and copyright: (C) Marling \& Kiib, first published in (Marling \& Kiib, 2011), with the authorization of the authors and editors.

13 In addition to these analyses, "inside out" studies have been conducted. They include indepth studies of city life using qualitative ethnographic methods, participatory observations and dialogue-based interviews. This included observations and interviews 
with twelve participants about their everyday life and territories at Roskilde Festival. The respondents were chosen to represent different ages, geography, sex, and according to whether they were festival beginners or experienced participants.

The respondents were followed over twenty-four hours and their experiences at the festival were documented. The respondents were asked to take photos of the places where they "felt at home" or where they felt that "something interesting" was taking place, and their preferences among the many cultural and social offers where monitored and analysed.

The concept "urban songline" is used in a dual meaning. On one hand it refers to the route, nodes and landmarks that each of us follows daily on our way through the urban landscape. In this sense a songline is a line or track we follow and which physically marks one's own urban territory. On the other hand, urban songlines are also mental tracks, places of cultural, social or historic meaning or places that we find intriguing. In this sense, urban songlines are tied to our social behaviour and mental memories and connections (Marling, 2003; Marling, 2012). In this way, the method combines mapping of everyday practice with sensory experiences of places.

The results of the mappings and analysis are conducted as a series of narratives - one for each respondent - and they are presented on psychogeographical maps and through photos and texts (Marling, 2004; Marling \& Kiib, 2011; Marling, 2012).

What we have traced and explored through this "songline method" were both the experiences of different participants in relation to specific installations, art and performative architecture and their experiences of the mood and atmosphere at the festival in general.

Our approach is inspired by M. Merleau-Ponty's phenomenological work. Merleau-Ponty draws attention to the importance of our senses as the way through which we experience our surroundings. At the same time he considers the senses as a significant part of the body. This implies that individuals not only experience but also actually create space, art and architecture via the body and the senses (Merleau-Ponty, 1994).

20 As we will see later, this approach is interesting in the context of the Roskilde Festival, as the participants are very cheerful and playful, and they occupy art and architecture in unexpected ways, often together with foreign festival goers. Roskilde Festival and its artists and architects work consciously to create a particular ambience or mood, and so do the participants in their own creations and camps.

21 Our studies of the ambience of Roskilde Festival - and of how the participants experience the mood and the atmosphere - has been inspired by G. Böhme and his approach to atmosphere as an aesthetic term. In his research related to mood as an aesthetic concept, G. Böhme defines atmosphere as follows: "Atmosphere is something between the subject and the object, therefore an aesthetic of atmosphere must mediate between the aesthetic of reception and the aesthetic of the product or the production." (Böhme, 1998, p. 112) Atmospheres fill spaces and places. They can be described by many different adjectives, such as a joyful atmosphere, tense, sad, obscure etc. In other words, we experience atmospheres as "quasi-objective, whose existence we can also communicate with others. Yet they cannot be defined independently from the persons emotionally affected by them; they are subjective facts." (Böhme, 1998, p.112-114) Böhme's definition of atmosphere as something mediating the aesthetic reception of people and artefacts is 
useful for us in our investigation of the role of architecture and art as a catalyst for the specific atmosphere at Roskilde Festival.

Illustration 6a: Interview with a festival participant. Songline Map

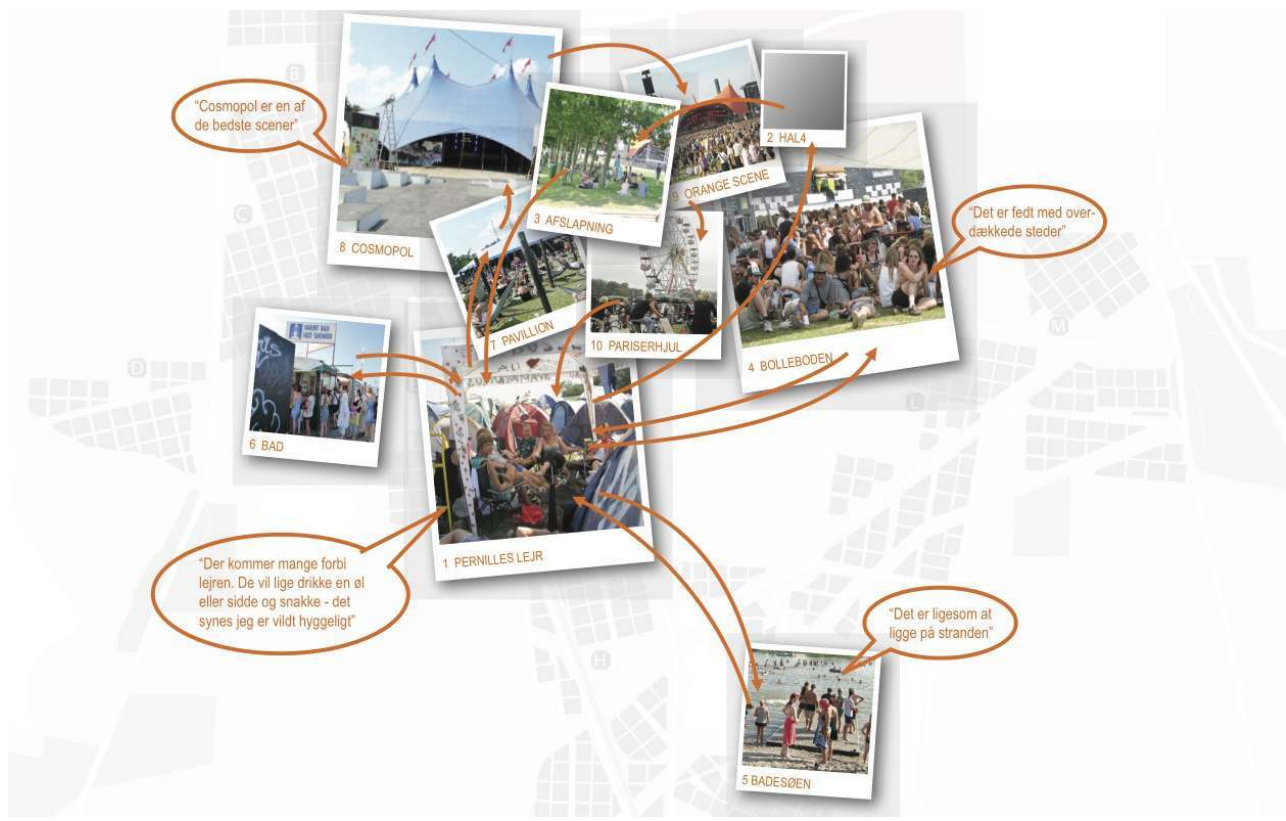

Source and copyright: (c) Marling \& Kiib, first published in (Marling \& Kiib, 2011, p. 141), with the authorization of the authors and editors. 
Illustration 6b: Interview with a festival participant

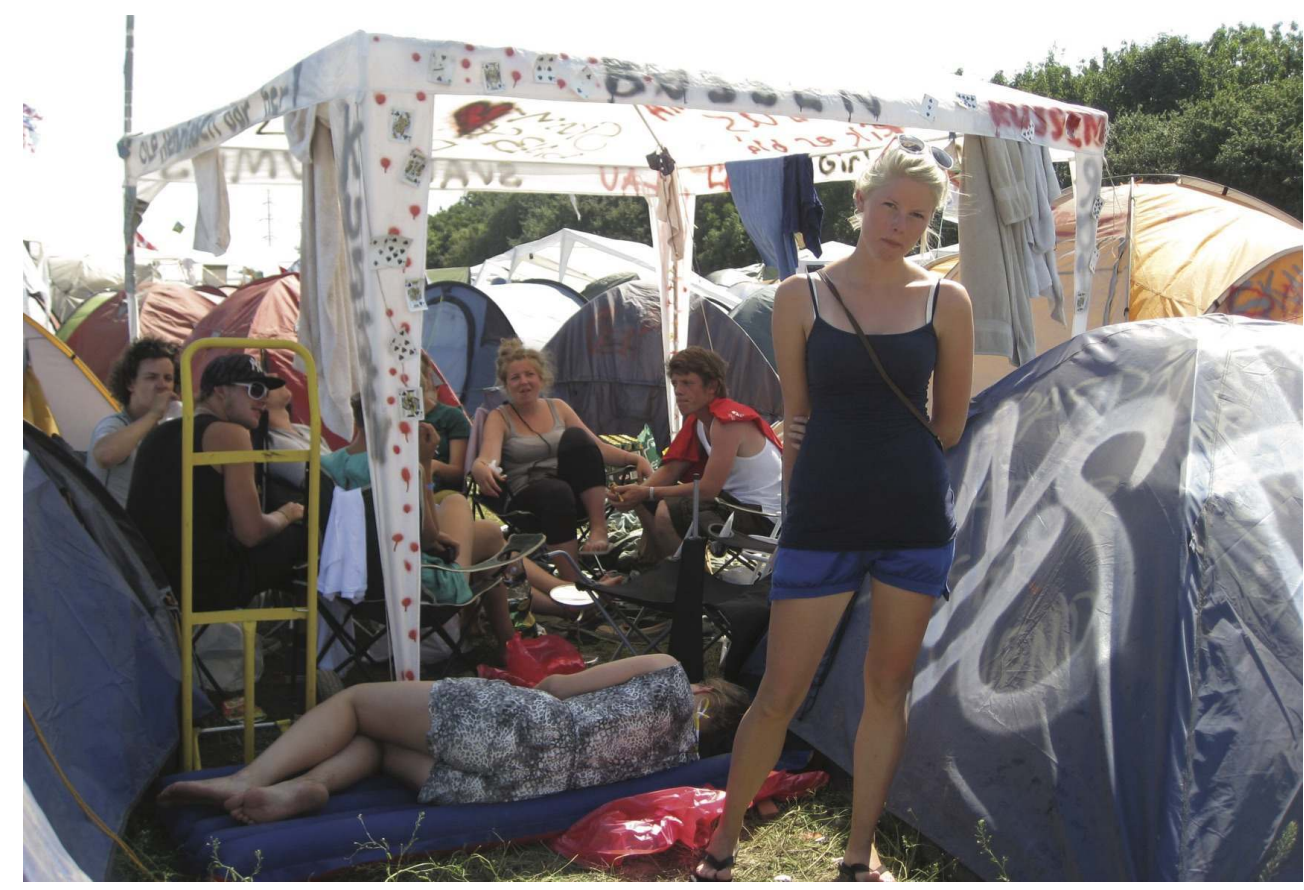

INTERVIEW WITH A FESTIVAL PARTICIPANT (PERNILLE KROgH). THE 'SONgLINE MAP' SHOWS HER TERRITORIES AND HER COMMENTS ON HER EMOTIONAL RELATIONS TO PLACES, ART, MUSIC AND EVENTS AT ROSKILDE FESTIVAL. PERNILLE TALKS AMONg OTHER THINgS ABOUT THE TUBORg FERRIS WHEEL: “YOU HAVE TO PEDAL FOR THREE MINUTES TO RIDE THE WHEEL. EVERYBODY'S PEDALLINg, AND IF ANYONE STOPS AND gETS OFF, YOU CAN FEEL IT gETTINg HEAVIER... YOU gET AN Egg TIMER... WE PEDALLED HARD FOR THREE MINUTES AND THEN SAW THE LAST THREE TRACKS OF THE CONCERT (KANYE WEST) FROM THE FERRIS WHEEL. IT WAS A COOL EXPERIENCE".

Source and copyright: (c) Marling \& Kiib, first published in (Marling \& Kiib, 2011, p. 141), with the authorization of the authors and editors.

\section{The Concepts of Roskilde Festival}

The Roskilde Festival extends over eight days, and is divided into two vastly different periods (four + four days). The first period of four days is called MOTION and it is open for self-organized performances, play, music, talks, art events and other diverse activities.

The second is called EMOTION and is the period of the more official programme, with music events taking place at the large locations.

There is no doubt that music is the main focus - Roskilde Festival is a rock festival, offering many shades of different genres. No other Northern European music festival can offer such a high-profile music programme with so many international celebrity names. There is a mixture of niche experiences and stars with a broad appeal, and a number of up-and-coming bands are given the opportunity to perform in front of a large crowd. We will come back to music and performance later. Now we will turn to the city life.

\section{An open-minded and inclusive city life}

City life is an important pillar on which the festival is based. It has to do with the party, the community building and individual expression, enhancing a barrier-breaking 
fellowship with people you know - but also with people you might get to know. City life has to do with what is perceived, and with taking part.

\section{Gemeinschaft and Gesellschaft} Ferdinand Tönnies and his terms "Gemeinschaft" (the local community life ruled by norms and traditions) and "Gesellschaft" (the life in global cities ruled by regulations and laws). Our analysis has also been inspired by George Simmel's approach to city life as both overwhelming, inspiring and interesting at the same time (Tönnies, 2005; Simmel, 1995).

Furthermore, Erwin Goffman's study of behaviour in public places (Goffman, 1966), together with Richard Sennett's arguments for the need of an open society and the rise of a publicly inclusive and social urban life, have influenced our observations (Sennett, 1995 \& 2005). Finally Martin Haajer \& Arnold Reijndorp's term 'public domain'- about urban places where a social and cultural exchange occurs - has been used to describe the character of the social interaction in the instant city of Roskilde Festival (Hajer \& Reijndorp, 2001).

\section{Rules and norms}

28 The individual is stimulated by the many new impressions. In the sphere of "Gesellschaft", one can free one's spirit from everyday practice and show sides of oneself that are "more than what I do ordinarily", as Simmel puts it (Simmel, 1995). As in any other city, the sphere of "Gesellschaft" at Roskilde Festival is regulated by rules and norms. There are security regulations, and there are norms and cultures, which ensure that everything functions properly. Time is an important factor due to the tightly scheduled and comprehensive concert programme. As evidenced by the interviews, the time schedule is perceived as being tight and at times a little stressful if there are specific concerts that must be attended.

A couple of quotes from the interviews however reveal that there is a significant difference between the formal culture at Roskilde Festival and that of any other big city: "The atmosphere (at Roskilde Festival) is very different"; "Everybody's very friendly and helpful"; "There is little to no violence at Roskilde"; "(There is) an unprecedented degree of respect", etc. (Marling \& Kiib, 2011, p. 135 and ff)

\section{Transparent communities}

The many camps with five to fifty people make up small "Gemeinschafts" where the inhabitants have closer relations; if not from the start, they will develop these relations due to the cramped environment and the transparency of the more intimate activities.

31 An examination of the communities that are formed in the camping areas at Roskilde Festival reveals that they are not closed. On the contrary, they are characterized by being open and inviting. The interviews illustrate that the participants visit each other's camps. People visit camps where they know the inhabitants, but they also drop by even if they do not know one another. Random neighbours are invited over for a party, a game of cards or, for example, beer bowling. The lines between the private and the public spheres may be there, but they are not very distinct; rather, they are transparent and somewhat 
blurred. A stranger dropping by or suddenly falling over immediately outside or halfway inside one's tent is a new and barrier-breaking experience for many of the festival guests.

Illustration 7: The "Gemeinschafts"

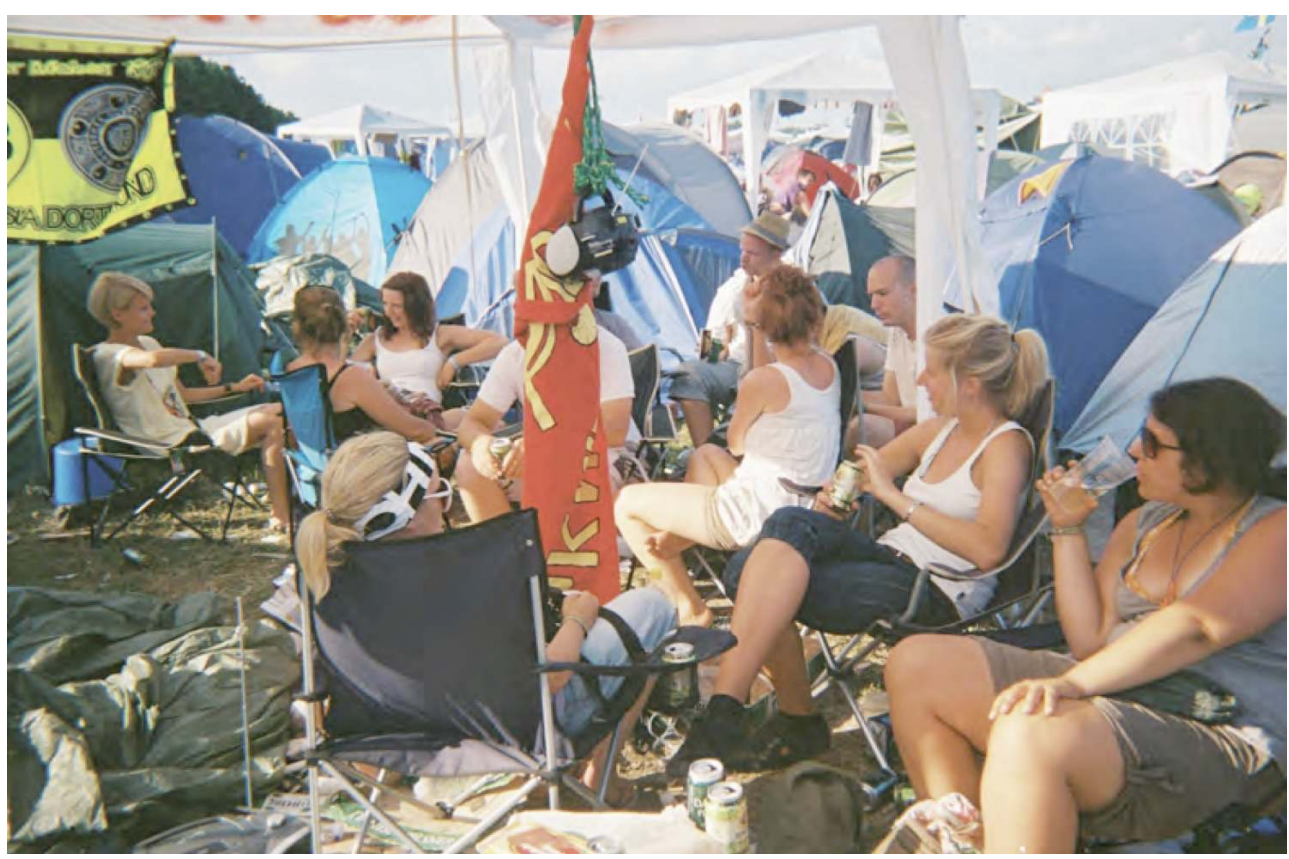

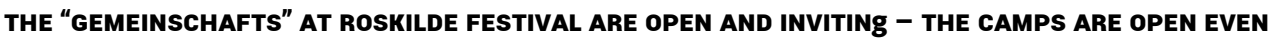
FOR STRANGERS JUST TO DROP

Source and copyright: ( ) Marling \& Kiib, first published in (Marling \& Kiib, 2011), with the authorization of the authors and editors.

Referring to the classical theories on urban life, the transparent "Gemeinschafts" (camps) of Roskilde Festival are thus one of the keystones in understanding the spirited city life with an inviting atmosphere of inclusion. Almost all of the respondents focus on the self-organized parties. People visit each other in their camps. Pernille notes: "Many people drop by the camp for a beer or a chat - I think that is really nice. A lot of different people drop by... also strangers who sit down because they think it looks nice. It's cool that they have the nerve!" (Pernille Krogh, 19-year-old girl from Aalborg, Denmark in: Marling \& Kiib, 2011 p. 137). The parties in the various camps open up the city life and the private domains. It is a point well worth noticing, as it has to do with a barrier-breaking principle in relation to the sphere of official city life.

\section{In search for more explanations}

City life at Roskilde Festival is, however, more than just "Gesellschaft" and "Gemeinschaft". At Roskilde Festival, no-one is merely a passive spectator. As soon as a guest enters through the gate to the festival area, he/she enters another world - 'a real second life' (Marling \& Kiib, 2011). It is a world that differs from the "permanent city" with its official culture in the form of well-defined social hierarchies, power structures, class-related norms and inherited values. This is not to say that there are no norms and traditions at Roskilde Festival - there are - but they often seem a bit twisted with an added measure of humour and craziness. 

centres and many of the private camps in the camping area too, comprise a large, 'openminded public domain' where a great deal of social and cultural exchange occurs. In spite of different spatial and architectural appearances, they share a common trait in the sense that young people of different backgrounds and from different geographical places test the city life and challenge their personal limits, as they put it themselves. The interviews with the participants clearly show that there is a different social order - often turned completely on its head - during this particular week. It is a feast with expression of the grotesque and a party filled with intoxicated experiences, humour and joy. The feeling of crossing the boundaries permeates city life and social interaction.

\section{Theory of laughter culture and grotesque realism}

Where does one find terms for this form of urban life? The regular theories of city life are insufficient here. Therefore, we have to look to literary theory, more specifically to the Russian literary theorist Mikhail Bakhtin, who worked with a concept he labelled "laughter culture". "Carnivalism and laughter culture" is the title of a Mikhail Bakhtin book that was published in Danish in 2001. Bakhtin takes as his point of departure Rabelais' picturesque descriptions of medieval carnivals and feasts, including ecclesiastical ones. He argues that they played an important role in the life of medieval people.

Bakhtin's interest lies in the question of the role of life and the carnival in everyday practice.

"The character of the carnival is universal; it is a particular condition of the entire society, a societal rebirth and renewal, in which everybody participates" (Bakhtin, 2001, p. 24).

Bakhtin reflects on the nature of the carnival as a part of life itself.

"Thus it is life itself which stages a carnival, or the play or the game becomes, for a while, life itself. Herein lies the specific nature of the carnival, the particular nature of its existence... The carnival is the life of the people, organized around laughter" (Bakhtin 2001, p. 29).

The medieval carnival was "temporary", which is an important point. The rulers and the church accepted the carnival solely due to its temporary nature. Bakhtin, this is a way of perceiving the world, life, human beings and their relation to other people. dimensions: "universality", "party", "freedom" and "ambivalence". Combined, these four dimensions comprise a utopian life in which people are cheerful, playful, open, equal and in harmony.

The laughter of laughter culture is social. It is not a personal reaction to some "amusing episode", nor is it negative or satirical. The laughter is complex, consisting of three parts:

- It is "all-inclusive and social", which means that everybody is laughing;

- It is "universal", which means that it is directed at everything and everyone, including the one who laughs him-/herself; 
- It is "ambivalent", which means that it is a happy and cheerful laughter, which might simultaneously be mocking and degrading. Carnival laughter degrades, it negates and confirms, and it buries and gives birth all at once (Bakhtin, 2001, p. 33).

The specific laughter of laughter culture should not be confused with either public criticism, with the satirist who uses satire for political purposes, or with that of revues, which aims to point fingers at others. In spite of its mocking and degrading aspects, carnival laughter has no such specific goals. On the contrary, the laughing person exposes and uses him-/herself as a medium in the amusement.

\section{Illustration 8: Nordic Viking}

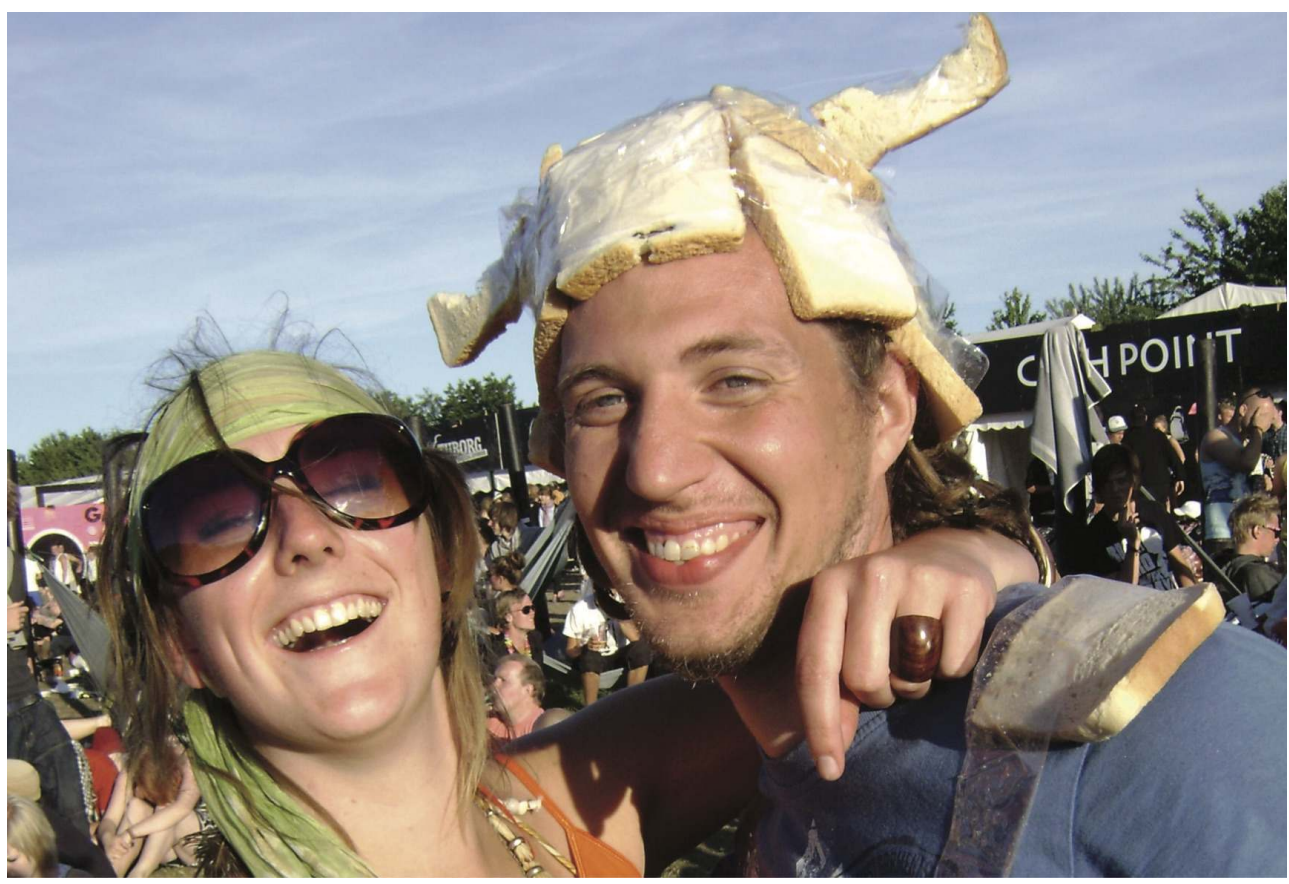

A NORDIC VIKINg: THOSE WHO LAUgH USE THEMSELVES AS MEDIA FOR THE AMUSEMENT

Source and copyright: () Jeppe Kiib, first published in (Marling \& Kiib, 2011), with the authorization of the authors and editors.

Grotesque realism is the aesthetic dimension inherent in laughter culture. Grotesque realism is the means by which laughter culture is expressed through idioms and imagery. As in laughter culture, the four dimensions of universality, ambivalence, party and not least freedom are significant.

However, Bakhtin also focuses on other dimensions, first of all the "physical - bodily", which refers to the fact that man eats, shits, drinks, fights, feasts and works. All of these material and bodily functions are present in laughter culture and expressed through grotesque realism.

Bakhtin adds yet another dimension: that of "negation". The term covers the complete transformation in grotesque realism of high and low, true and false.

According to Bakhtin, degradation often takes place. The degradation is not obliteration, though. Degradation means that things are brought down to earth and become one with the earth. It is a burial, but also the sowing of the seed of something new and improved. The degradation is thus ambivalent because it simultaneously negates and confirms (Bakhtin, 2001, p. 45). 
Finally, Bakhtin refers to "exaggeration". During the carnival, the body is presented with big breasts, giant bottoms, large heads with big mouths and ears (Bakhtin, 2001, p. 13).

Illustration 9: Graffiti

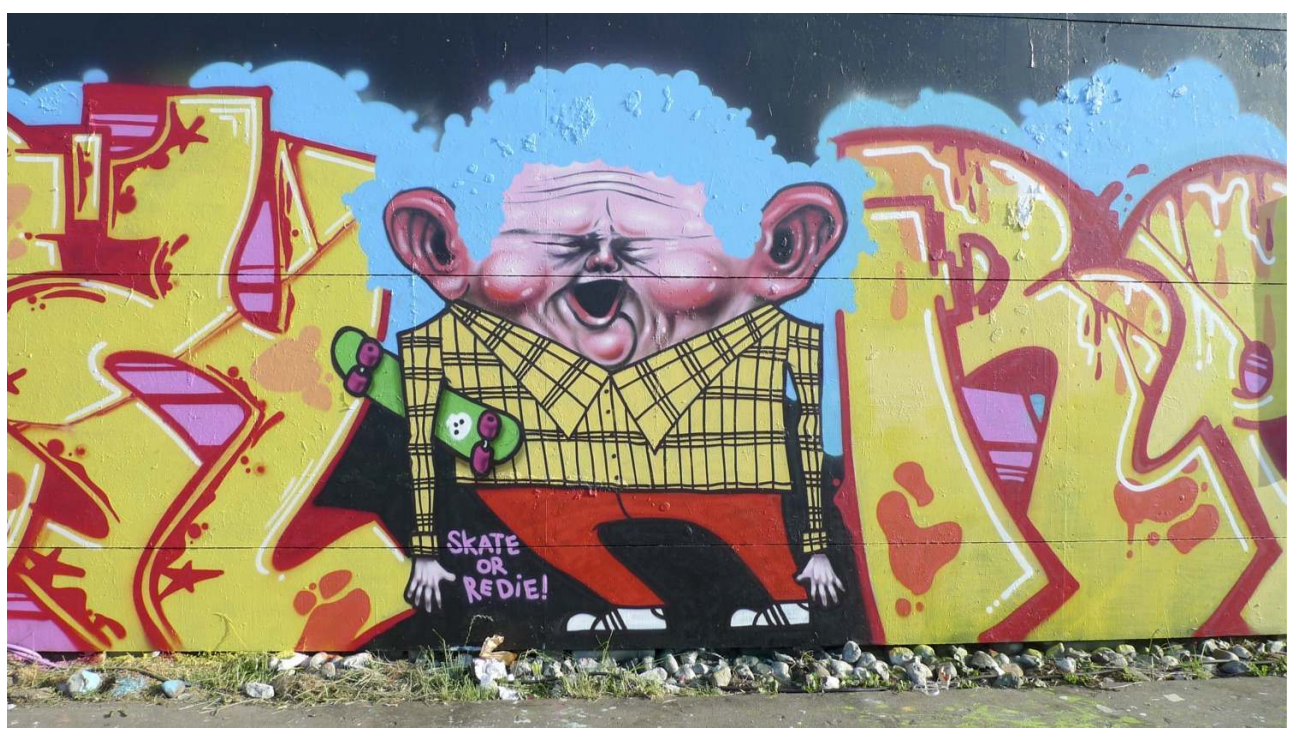

GRAFIITI ART AT THE SKATE STAgE: THE BODY IS PRESENTED WITH A LARgE HEAD AND WITH BIg MOUTH AND EARS. THIS IS AN EXAMPLE OF EXAggERATION

Source and copyright: (C) Hans Kiib, first published in (Marling \& Kiib, 2011), with the authorization of the authors and editors.

\section{Laughter culture penetrates city life at Roskilde Festival}

The observations at Roskilde Festival and the narratives from there show that laughter culture greatly influences public behaviour at the festival. For a limited period, the participants find themselves in the "realm of freedom". Most of them explicitly say so. Several respondents characterized Roskilde Festival as an extended party. They point out that the party is different from parties in the permanent city, where participation only lasts a short while. At Roskilde Festival, they spend an entire week with their friends, which they find stimulating for the friendship.

\section{Time}

If we begin by looking at the time factor, Roskilde Festival is, as previously mentioned, a party with a fixed duration. Its temporary character means that there is an extended framework for the festivities. The party and the experiments pose no threat to official society because after a week they will disappear again. Moreover, they have no direct political or religious agenda, as Roskilde Festival is religiously and politically neutral.

It does, however, provide an opportunity to get away from everyday norms, demands and expectations and from other forms of behavioural regulation found in modern societies. 


\section{Freedom}

51 Roskilde Festival is consequently an event that allows the participants to loosen up. This aspect of freedom is significant. The freedom resides in "the opportunity to do nothing and anything", as many of the interviews show. According to our respondents it is the freedom to enjoy life and to party without inhibitions for a week. Freedom is to shelve one's inhibitions in several kinds of ways, as one of the respondents says.

52 You do not find any dress code; everybody can come as they are. Or they can dress up or change style - get rid of the suit or the neat and orderly surface of official life. One respondent stresses the incredible degree of tolerance and respect and says, "You can get away with almost anything" (Marling \& Kiib, 2011, p. 135 and ff).

53 The freedom is also expressed in grotesque realism, such as enjoying being in a camp full of garbage; several respondents enjoy "not having to clean up all the time".

54 Consequently, most camps are a complete mess. It is almost tempting to posit the garbage as a "grotesque aesthetic symbol of freedom".

\section{Body}

The freedom is also evident in a naturist culture, such as in getting "a buzz" out of being naked in a unisex sauna or shower, or "running naked through some camps". It is "barrier-breaking and awesome to act it out", a respondent says (Marling \& Kiib, 2011, p. 135 and ff).

Bodily functions that are considered private in official city life are displayed freely at Roskilde Festival. People sleep, make love or vomit in public, but it does not feel unnatural. I can be observed - and several respondents also mention the fact that both women and men in particular urinate in the open.

If one were to stay in a random spot in the festival area, one would soon see participants in colourful, often very scanty costumes and outfits that exhibit the body - or degrade the participant as a humorous comment on his/her own role or ego. As a "small party", the dressed-up people drift by, spreading joy and fun to everybody; amusing episodes occur, which would be too much in ordinary, routine city life, but at Roskilde Festival, they are simply a part of the laughter culture. 


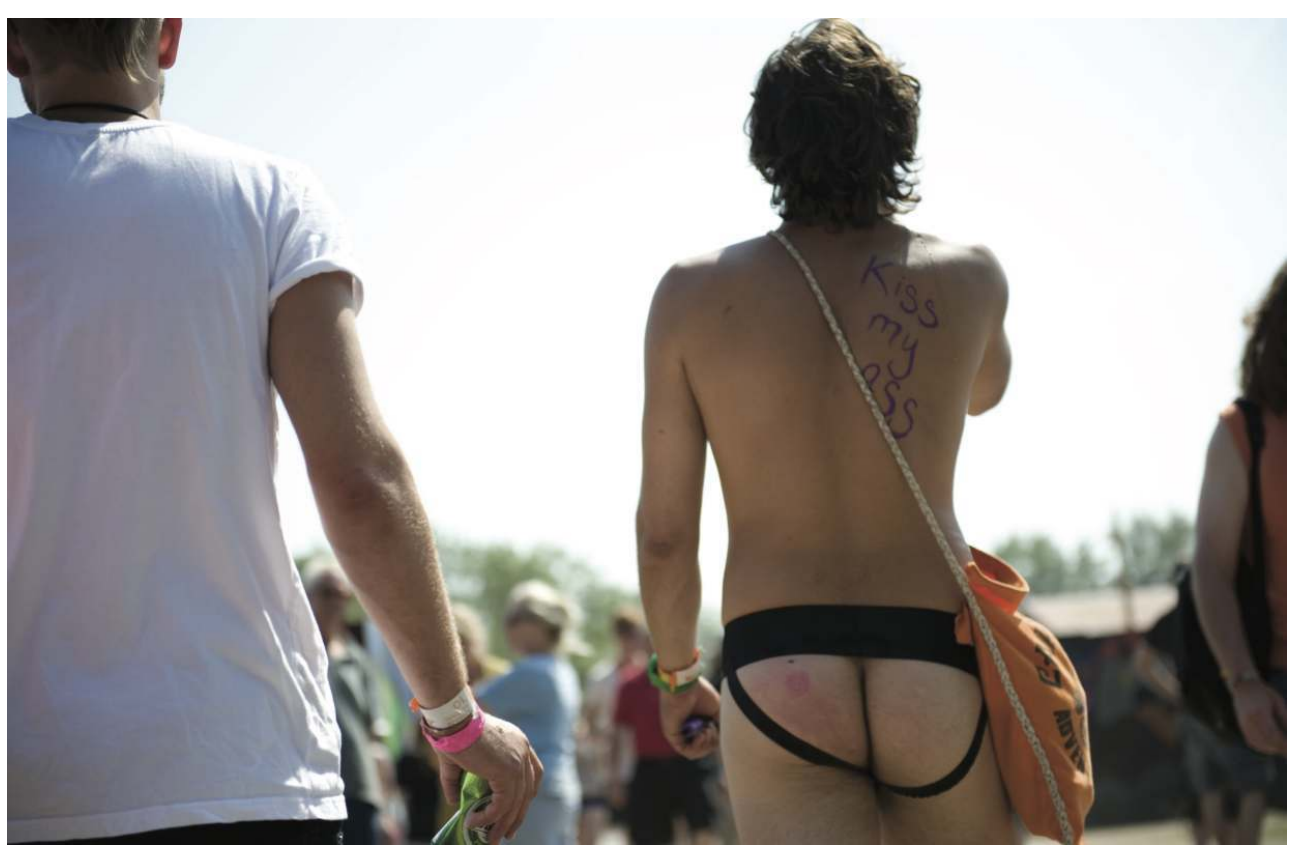

THE BODY IS EXPOSED IN THIS SELF-ORgANIZED PERFORMANCE

Source and copyright: ( ) Jeppe Kiib, first published in (Marling \& Kiib, 2011), with the authorization of the authors and editors.

The example illustrates the kind of physicality that, in the words of Bakhtin, "opposes anything exalted, spiritual, and which is not a part of the body" (Bakhtin, 2001, p. 40 and ff).

\section{Universal}

The laughter culture at Roskilde Festival is universal. Everybody is participating! Everybody is living it!

Much of the universal element of laughter culture is found in the self-orchestrated events and is advertised on Facebook - everybody is invited, and everybody contributes to the party.

61 It is, as expressed by Bakhtin, a social kind of laughter. Everybody is laughing. The one who is laughing also laughs at him/herself. The self-organized parties such as "Where's Waldo?" and "Royal Day" with the princess costumes, the "Bob the Builder" camps and "The Naked Run" exemplify how the participants make fun; but the people who are making fun also laugh at themselves while running around in silly, often grossly exaggerated, costumes.

\section{Music in the small print}

62 The music programme is very diverse. When the year's musical line-up is released there is normally extensive discussion of who is going to play on the Orange Stage. However, it is good advice is to remember to "read the small print" in the programme. An overwhelmingly broad programme is hidden here: a lot of interesting and upcoming 
bands and a mix of rock, alternative rock, pop, hip hop, metal, techno, dance, world music, rap and melodic acoustic music. More than hundred performances are on offer.

Laughter culture and the grotesque also permeate the music and the art installations at Roskilde Festival - especially the programme "in the small print". The band Slipknot includes strong elements of ambivalence, exaggeration and degradation. Other bands cultivate grotesque realism in the lyrics and music. One of the best examples of this is the rap group Malk de Koijn and their eloquent lyrics with grotesque references to sex and bodily fluids.

For the audience, the concerts and the pure sonic enjoy are often mixed up with additional bizarre experiences. It can be the experience of moving from concert to concert one evening and thus creating a very ambivalent musical experience.

"I went from Lucy Love to cellos which were playing like guitars to death metal. It was special and amazing to get this musical experience blown in your face in such a strange context" one respondent says (Michael 26 years old, student, musician and experienced participant from Copenhagen, in Marling \& Kiib, 2011, p. 219).

Another speaks of the Trentemøller concert, which was a particularly good experience with a great atmosphere. "When thousands of people work together to create the party, when they dance so close together and are in touch with the music, you forget yourself. There is a free and uninhibited atmosphere... It's an extraordinary experience driven by synergy and a mutual feeling of belonging," says Simon, a 19-year-old high school student from Aarhus, in Marling \& Kiib, 2011, p. 149).

\section{Theories on relational art and performative architecture}

Roskilde Festival offers more than music - it has become a living laboratory for art, installations and instant architecture. The festival aims to develop instant architecture which is flexible, cheap, constructed of sustainable and reusable materials and which creates interaction and engagement between the visitors. The temporary constructions are going to have numerous functions: to invite people to sit, relax or hang out, but also to be platforms for different activities. They also have to give the users a new experience, cause them to think, sense, feel or reflect. In that respect the approach is what architect and architectural theorist Ann Klingmann in her work labels "performative architecture" and art. 
Illustration 11. Sculpture or 'think-construction' at Roskilde Festival 2009.

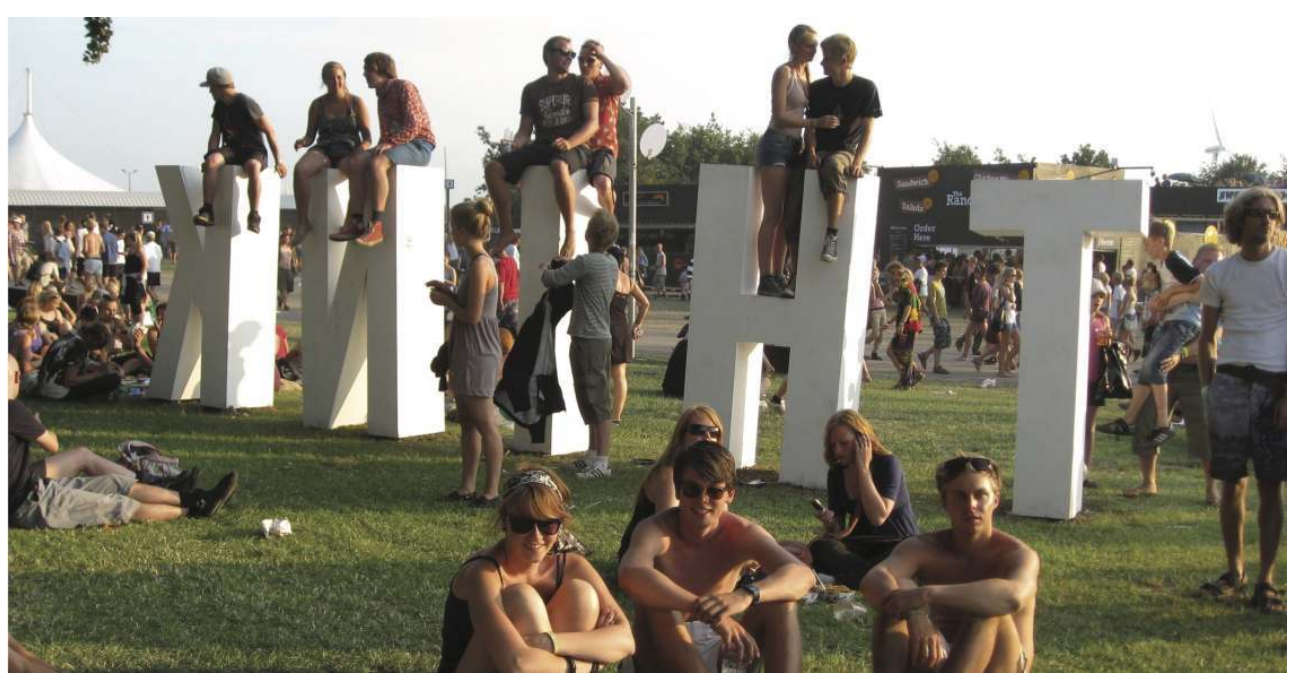

YOU LOOK AT IT - YOU CLIMB ON IT AND YOU REFLECT ON IT. IT WAS LOCATED JUST NEXT TO A SMALL MEMORIAL PARK FOR THE FESTIVAL-gOERS WHO DIED AT THE 2000 FESTIVAL.

SOURCE AND COPYRIgHT: fIRST PUBLISHED IN (MARLINg \& KIIB, 2011), WITH THE AUTHORIZATION OF THE AUTHORS AND EDITORS.

She draws attention to the increased focus on architecture as "brandscapes" and in this respect she refers to theories on "experiential marketing", which take as their point of departure the notion that experience is not embedded in the product in advance, but is rather something that must be added. Klingmann develops four categories. First there is the category of "sense architecture", which appeals to the user's senses with the purpose of creating an experience through sight, hearing, touch and smell. Then there is "feel architecture", which appeals to the user's emotions; "think architecture" appeals to his or her reflections and memories and also attempts to create an inner mood. Finally there is "act architecture", which aims to enhance physical exertions and interaction (Klingmann, 2007; 2009). Performative architecture, as defined by architects and researchers Branko Kolarevic (2005) and David Leatherbarrow (2005), characterizes a change from appearance, from what architecture looks like, to performance, what architecture does. This idea implies that architecture plays an active part when it comes to the staging of certain actions and behaviours.

At Roskilde Festival installations that fit, support and even fuel the festival culture are commissioned, in order to support an atmosphere of social exchange and inclusion among the festival guests.

The installations at Roskilde Festival generally aim at engaging the audience in a very physical, bodily interaction, and the installations have participation and interaction as the most important aesthetic feature. Theoretical approaches such as performance studies and performativity theory can provide useful insights into how to describe and understand the focus on the bodily presence and interaction in the installations. When we look at performance studies, we are particularly inspired by theory related to cultural studies.

70 Performance Studies was founded as a discipline mainly during the 1960s and 1970s, when researchers from a range of disciplines within the social sciences such as sociology, anthropology and ethnography utilized and applied terms and concepts from traditional 
theatre studies to the study of everyday life (Carlson, 2004). The concepts and vocabulary of theatre/drama have the ability to capture and analyse performance in everyday life, as a form of non-verbal communication, and they can be applied to the study of a broad variety of cultural phenomena. Sociologist Erving Goffman defines performance as "all the activity of a given participant on a given occasion which serves to influence in any way any of the other participants" (Goffman, 1959, p. 15-16). In this particular case, we study behaviour and performances in and around the festival architecture, and how the spaces facilitate these performances, as it is in these performances that the special features of the festival culture of Roskilde Festival, the so-called "Orange Feeling", is played out. The installations at Roskilde Festival have scenic or stage-like qualities, so the installations become the scenography for the performed culture of the festival participants. While performance and performativity take place regardless of whether the participants/performers are conscious of it or not, the concept of the "theatrical" is characterized by a high level of consciousness of the roles of performers and audience in relation to the performance. Artistic director and art theorist Solveig Gade defines the theatrical as "an event that takes place in the meeting between viewer and performer and ... takes place in a staged space, where phenomena mean and are interpreted in another way than in daily life" (Gade, 2010, p. 44, authors' translation). The installations at Roskilde Festival are conceived as a means to create situations where the participants can take on various roles in and around each installation.

71 If you accept the installations' invitation to active participation, you become a performer whom others can watch, and they become an audience. The active participants animate the installation with their bodily presence and thereby turn it into a spectacle. The grotesque realism and the humorous tone that are important features of the installations mark the festival culture's distance from everyday culture, by subverting the norms and rules of everyday life.

The installations at Roskilde Festival relate to the overall "performative turn" within the humanities. In contemporary art, the performative turn has been investigated by several theorists who have, for example, defined it as a social turn (Bishop, 2006), as relational aesthetics (Bourriaud, 2002) and as a shift "from site to situation" (Doherty, 2004). The common features are direct involvement and engagement of the audience in the realisation of the artwork, and the participants and their actions being considered to be part of the artist's materials. The result is a situated aesthetics which is bound in time and space, and therefore emphasises the presence of all participants there. Art theorist Camilla Jalving states that to analyse and understand the performative art works, it is necessary to direct one's focus also on the effect of the artwork on the audience, and the site - that is, on the situation of which the artwork is a part (Jalving, 2011).

\section{Grotesque realism and relational art installations}

73 In the following we will present examples of our analyses of both projects that have been commissioned from recognized art groups and the more self-orchestrated projects. In our analysis we focus on the effects of the projects: the performances and the situations these installations create at the festival. 


\section{Pose/Expose}

74 by the Danish artist duo AVPD. The pavilion has a diameter of 8 metres and is approximately 2.5 metres high. The pavilion is raised from the ground on two steps which encircle the whole structure, and offer the possibility for sitting down along the façade. The façade itself is clad in a two-way mirror foil, which is reflective on the brightest side of the pane and appears transparent from the darker side of the pane. That means that during the day, the pavilion has a mirror façade which reflects the busy festival life in the area surrounding the pavilion, while at night time, when lights are turned on inside the pavilion, the façade changes character and become transparent to the people outside of the pavilion, and they can watch what happens inside, while the people on the inside get the feeling of being in an enclosed, intimate space with mirror walls. The high-tech material is well known from the building industry, where it can be used to create undisturbed workspaces, but in the festival context the material is used in a nonrestrictive and playful manner. The one-way mirrors create a kind of unidirectional sense of cohesion, and the material intervenes in the relation between inside and outside. It is only possible to fully understand this difference if you have been inside the pavilion.

Inside Pose/Expose is a so-called silent disco. A silent disco is an event where al participants dance to music from headphones, so you cannot be sure that everyone is listening to the same music, and spectators, who do not hear the music, can only watch the dance movements of the crowd. The interior of Pose/Expose can be described as a non-hierarchical, centralized dance floor, where many dancers can fit in at once. No-one has a better spot than anyone else, and everyone gets the same quality of music in the headphones. The participants dance freely around and amongst each other in unpredictable patterns. The dance floor in Pose/Expose can be interpreted as a stage for a performance, where all those who are present also are part of the performance. This is especially so at night time, when the dance performance can be seen from outside, and the light inside the pavilion turns the whole situation into an animated lantern in the festival landscape. The experience of Pose/Expose is loosely choreographed: it is possible to stay in the pavilion for both long and short visits, and it is the mood, temperament and inclination of the audience that defines the extension of the experience. The theme and title of the pavilion point towards aspects of living and partying as closely together as the participants do at the festival. At the festival you are exposed in all spaces, so looking at others and being looked at is a constant condition, and Pose/Expose is designed as a space for exposure in order to address this trait of the festival culture artistically. Artworks like Pose/Expose rely on the willingness of the audience to step onto the stage, and submit to the rules of the game that the installation offers, and the audience at Roskilde Festival are very eager to participate. Many festival guests enjoy dancing together with their friends in this kind of 'social solitude' inside the headphones, as a contrast to the huge concerts. Any reservations or shyness are gone. The festival behaviour is fuelled by music and alcohol, but installations like Pose/Expose provide a spatial setting that is aimed at social situations and designed for activities where the participants get to interact with each other. 


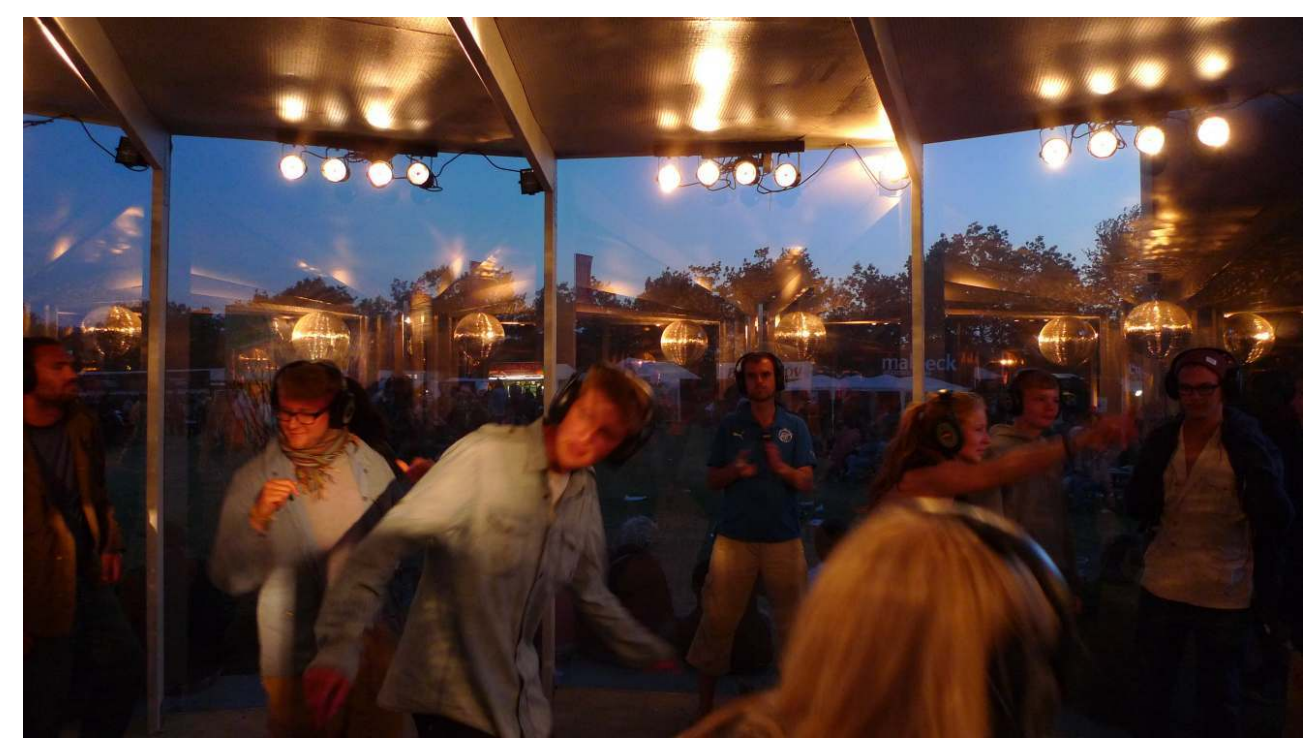

Source and copyright: ( ) Line Marie Bruun Jespersen, first published in (Marling \& Kiib, 2011), with the authorization of the authors and editors.

\section{Human Car Wash}

Ambivalence - as a principle of laughter culture and grotesque realism - is seen in many projects at Roskilde Festival in which things are turned upside down.

In the "Human Car Wash" project from 2009, it is not the car that is washed, but people, who are dragged through the drum, hosed down and washed. Human Car Wash, which is a Diesel clothing shop, is located on one of the busiest streets in the festival area and offers an unexpected and manufactured situation - a pause in the flow. The installation is a graffiti-covered building containing a wash bay with rotating brushes, resembling a car wash. Surrounding the Car Wash is a painted façade with a number of amusing and grotesque figures, signs and texts that provide information about the services on offer in a derogatory manner.

Outside the wash bay there are three rows of car seats with head rests placed on a small podium. The washing inside the bay is visible from the seats through some large windows. On the façade, there are speakers reproducing the participants' voices underscored by low-volume music. Inside the wash bay there are showers along a catwalk. Assistants help small groups to get ready to be showered. The participants laugh and fool about at first in an attempt to cope with the awkward situation but, as their confidence grows, they start helping each other with the underpants and bikini showers - men and women in the same process.

79 Spectators in the car seats comment aloud on the events inside the wash bay. They hoot and cheer approvingly - but also the passers-by take a look and become a part of the bizarre spectacle... like a reality show with images, sounds and greasy windows. 


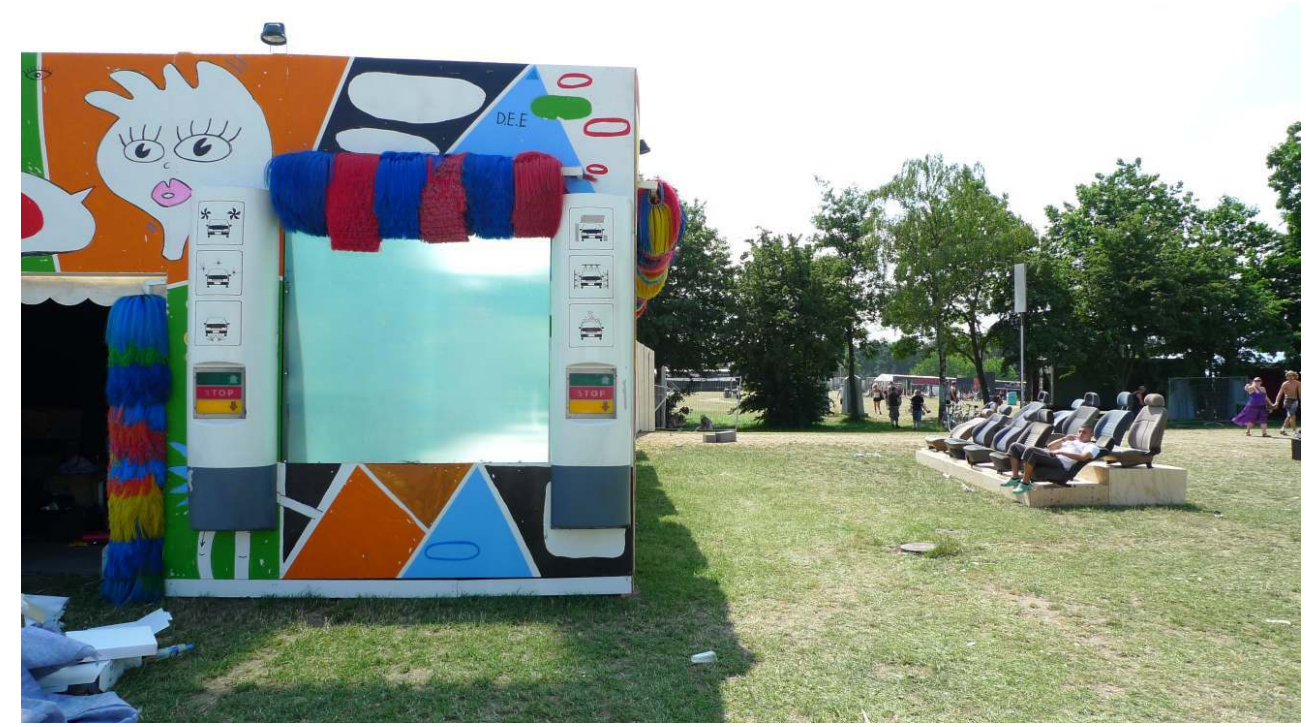

Source and copyright: ( ) Hans Kiib, first published in (Marling \& Kiib, 2011), with the authorization of the authors and editors.

\section{Illustration 13b. "The Human Car Wash - Installation"}

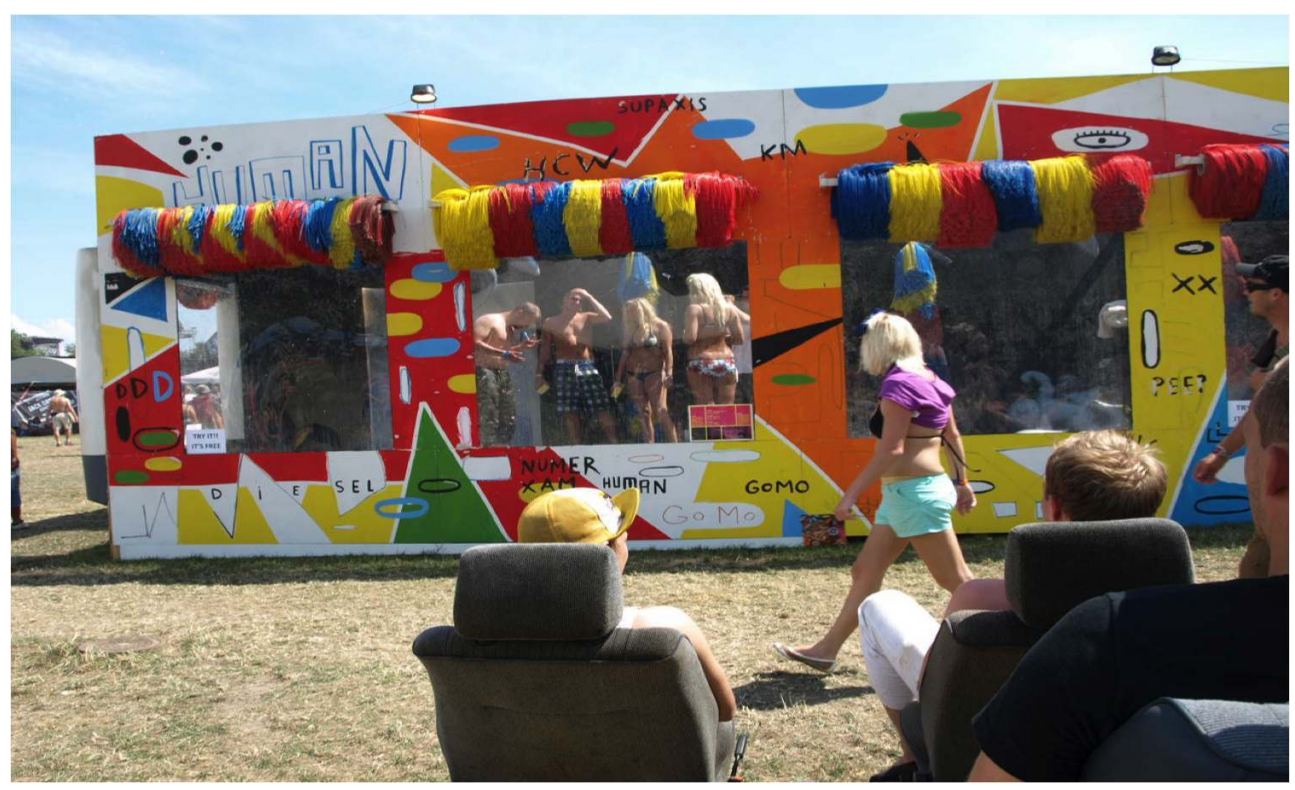

"The Human Car Wash - Installation" buries the capitalistic world's materialism (the car) - and at the same time the care for humans is reborn. That is the atmosphere of lightness, laughter and freedom in combination with open-mindedness and human responsibility.

Source and copyright: ( ) Hans Kiib, first published in (Marling \& Kiib, 2011), with the authorization of the authors and editors.

80 The construction itself is simple. But the baroque setup and the contrast between the intimate space behind the windows and the public space in front of them underline the sophisticated orchestration. This is an example of performative architecture that demands active (bodily) participation and is sensuous at the same time. 
81 The two examples - the art project Pose/Expose which is commissioned by the festival, and the Human Car Wash, commissioned by the commercial brand Diesel - both offer the audience the possibility of engaging in a staged performance. The participants perform as dancers or expose their undressed bodies in the shower. Both installations invite one to a bodily performance; they play on the distinction between "public" and "private", and they refer to the annulment or reversal of these distinctions in the festival context.

\section{The Orange Feeling - conclusion on culture and counterculture}

It can be concluded that as a specific mood and atmosphere of the instant city, Roskilde Festival is a collective feeling present in the moment, in an eruption of built-up, collective euphoric utopia. But it is also an atmosphere related to the different experiences in everyday life at the festival. Our findings are that Roskilde Festival attempts to create designs and design concepts which promote these particular atmospheres of freedom, of public laughter, of coherence and community. Referencing the colour of the large stage, this atmosphere is labelled "The Orange Feeling".

As we have seen, "The Orange Feeling", in the case of Roskilde Festival, can be produced via intentional designs and via different arrangements. However, it can also emerge as an atmosphere built up over the years between the participants, and already played out in the first four days of the festival through self-organized arrangements, events, parties, art and installations. Roskilde Festival has, in a way, become a city life laboratory and a learning lab for performative architecture and spaces. Roskilde Festival succeeds in creating new environments and installations that, in a manner of speaking, turn the nice design of the city upside down - into a "deturned city design" (see Sadler, 1999 \& 2005).

This works through music and art "in the small print" - e.g. up-coming bands, and through temporal architecture, installations, signs and urban space designs. The result is a combination of the concept of the festival and self-organized parties and happenings, a constructed situation composed in an atmosphere of universality, party, freedom and ambivalence.

Roskilde Festival is a "twisted version of city life", and it is "laughter culture" and "grotesque realism" which influences all the themes of the festival concept. Many dimensions of the urban cultures meet and intersect in a hybrid counterculture. This eclectic culture pops up everywhere, not least during the first four days in the camping area, where the participants are in control of most things, and where humorous elements and grotesque aesthetics contribute to an atmosphere of festive utopianism.

36 Together with the music, it is the memories of this atmosphere that remain with the many participants when they look back at that year's festival and eagerly announce their presence the next year. As quoted from Brostrøm: "It is the therapeutic and tenet-less cheerfulness and its will to rise beyond narrow-mindedness which enables the release" (Brostrøm, 2003, p. 34).

It is reasonable to claim that the public laughter is the decisive engine that makes the city life of Roskilde Festival operate in a way that is radically different from what can be observed in permanent cities and in more commercial festivals. It is also "the public laughter" that twists the music and performance programme and even the concept of the "Human Agenda - from attitude to action". The laughter has cleansing properties and 
ousts the hardships of everyday life at the festival - the heat and the thirst, the cold and the rain, the queues and the controls, and the miserable gravel pit that is the cause of the dust and the unreasonably long distances.

"The Orange Feeling" is expressed through open-minded and inclusive social interaction. The meeting between strangers becomes an essential theme of the self-organized parties on the camping site and in the installations on the festival site. Festival life is an extreme form of public life, where almost no private spaces exist, and this theme is addressed by turning normal life on its head: by making the private public, and exaggerating activities in grotesque forms, when it comes to both the social and the physical norms of human interaction. Our analyses of the installations show that architecture and art at Roskilde Festival function as a catalyst for an all-pervasive playful and socially inclusive laughter culture. It is in the culture of laughter that one finds the atmospheric glue that keeps Roskilde Festival together, and it is the culture of laughter that creates the basis for "The Orange Feeling".

\section{BIBLIOGRAPHY}

Bishop, Claire. 2006. The Social Turn: Collaboration and Its Discontents. Artforum february, p. 178-183.

Bourriaud, Nicolas. 2002. Relational Aesthetics. Paris: Les Presses du Réel.

Brostrøm, Torben. 2003. Uden Titel - littercere essays. København: Gyldendal.

Böhme, Gernot. 1995. Atmosphäre. Essays zur neuen Ästhetik. Frankfurt Am Main: Suhrkamp Verlag. Böhme, Gernot. 1998. Atmosphäre als Begriff der Ästhetik, Atmosphere as an Aesthetic Concept. Daidalos, $\mathrm{n}^{\circ}$ 68, p. 112-115.

Carlson, Marvin. 2004. Performance, a critical introduction. London: Routledge.

Doherty, Claire. 2004. Contemporary Art: From studio to situation. Bristol: Black Dog Publishing.

Gade, Solveig. 2010. Intervention \& Kunst. Socialt og politisk engagement $i$ samtidskunsten. København: Rævens Sorte Bibliotek.

Goffman, Erving. 1959. The Presentation of Self in Everyday Life. Garden City / New York: Doubleday. Goffman, Erving. 1966. Behavior in public places - Notes on the Social Organization of Gatherings. New York: The Free Press.

Hajer, Maarten \& Reijndorp, Arnold. 2001. In Search of New Public Domains. Rotterdam: NAI Publishers.

Jalving, Camilla. 2011. Verk som Handling. Performativitet, kunst og metode. København: Museum Tusculanum.

Jespersen, Line Marie Bruun. 2011. Urbane Installationer. Unpublished Ph.D dissertation.

Department of Architecture and Media Technology. Aalborg: Aalborg University.

Kiib, Hans (eds.). 2010. Performative Urban Design. Skive: Aalborg University Press. 
Klingmann, Anna. 2007. Brandscapes. Architecture in the Experience Economy. Cambridge Massachusetts: MIT Press.

Klingmann, Anna. 2009. Creative Brandscapes, Heroes with Flaws. In: Kiib, Hans (eds.). 2010. Performative Urban Design op.cit. p. 30-39.

Kolarevic, Branko. 2005. Towards the Performative in Architecture. In: Kolarevic, Branko \& Malkawi, Ali M (eds.). Performative Architecture: Beyond Instrumentality. New York / London: Spoon Press. p. 203-215.

Leatherbarrow, David. 2005. Architecture's unscripted performance. In: Kolarevic, Branko. \& Malkawi, Ali M (eds.). Performative Architecture op.cit. p. 5-21.

Lynch, Kevin. 1960. The Image of the City. Cambridge Massachusetts: MIT Press.

Marling, Gitte \& Kiib, Hans. 2011. Instant City@ Roskilde Festival. Skive: Aalborg University Press. Marling, Gitte; Kiib, Hans \& Jensen, Ole B. 2009. Experience City. DK. Skive: Aalborg University Press.

Marling, Gitte. 2004. Urban Songlines, Aalborg: Aalborg University Press.

Marling, Gitte. 2012. Urban Songlines - the City Experienced by Ordinary People. In: Andrade, Victor; Smith Shelley \& Lanng, Ditte Bendix (eds.). Musings - an Urban Design Anthology. Aalborg: Aalborg University Press. p. 142-153.

Merleau-Ponty, Maurice. 1994. Kroppens Fænomenologi. København: Det lille Forlag.

Smith, Shelley; Andrade, Victor \& Lanng, Ditte Bendix (eds.). 2012. Musings - an Urban Design Anthology, op.cit.

Pallasmaa, Juhani. 2005. The Eyes of the Skin. Architecture and the Senses. West Sussex: John Wiley \& Sons Ltd.

Rasmussen, Steen Eiler. 1959. Om at opleve arkitektur. København: Arkitektens Forlag.

Sadler, Simon. 1999. The Situationist City. Boston: Massachusetts Institute of Technology.

Sadler, Simon. 2005. Archigram, Architecture without Architecture. Boston: Massachusetts Institute of Technology.

Sennett, Richard. 1995. Community becomes Uncivilized. In: Kasinitz, Philip (eds.). Introduction to Metropolis - Center and Symbol of our Times, New York: New York University Press. p. 226-249.

Sennett, Richard. 2005. Democratic Spaces. In: Dean, Penelope (eds.). Hunch 9: Disciplines. Rotterdam: Episodes publishers. p. $40-47$.

Simmel, Georg. 1995. The Metropolis and Mental Life. In: Kasinitz, Philip (eds.). Introduction to Metropolis op.cit. p. 30-45.

Tönnies, Ferdinand. 2005. Gemeinschaft und Gesellschaft. Grundbegriffe der reinen Soziologie. Darmstadt: Wissenschaftliche Buchgesellschaft.

Venturi, Robert; Brown, Denise Scott \& Izenour, Steven. 1972. Learning from Las Vegas. Cambridge Massachusetts: MIT Press.

\section{ABSTRACTS}

This article investigates the relationship between instant architecture, art installations and the audience at Roskilde Festival, and it raises the question of how instant architecture, art 
installations and modes of social interaction can enhance the design of a genuine experience. It is based on analyses of a specific case, Roskilde Festival 2008 - 2012. The festival brands itself as an instant city with a specific atmosphere, 'The Orange Feeling', which is a very abstract term that encompasses the whole festival. The paper focuses on this term, and on important elements which constitute the environment and the conditions for the constructed situation in which this special atmosphere actually occurs.

The main approach to the analysis of the atmosphere is an investigation of how the audience engages with the instant architecture and the art installations. The article provides general conclusions on the specific atmosphere and on how the designs support this. It concludes that the culture of laughter is the atmospheric glue that keeps Roskilde Festival together, and it is the performative and relational designs together with the culture of laughter that create the basis for 'The Orange Feeling'.

Cet article analyse la relation entre l'architecture éphémère, les installations artistiques et le public du Roskilde Festival, et il soulève la question de comprendre comment cette architecture éphémère, ces installations artistiques et les modes d'interaction sociale peuvent améliorer la mise en forme d'une expérience authentique. Il est basé sur plusieurs analyses d'un cas particulier, le Roskilde Festival 2008 - 2012. Le festival se promeut lui-même comme une ville éphémère avec une atmosphère particulière, "The Orange Feeling", une expression très abstraite qui recouvre l'ensemble du festival. L'article se concentre sur cette expression, et sur les éléments importants qui constituent l'environnement et les conditions de la situation construite dans laquelle cette ambiance spéciale se manifeste.

La principale approche pour l'analyse de l'ambiance est une enquête sur les manières avec lesquelles le public s'approprie l'architecture éphémère et les installations artistiques. L'article propose des conclusions plus générales sur cette ambiance particulière et sur le rôle des mises en forme des lieux dans sa manifestation. Il conclut sur le fait que la culture du rire est le liant atmosphérique qui maintient l'unité du Roskilde Festival, et que ce sont les mises en forme performatives et relationnelles, jointes avec la culture du rire, qui créent les bases de "The Orange Feeling".

\section{INDEX}

Mots-clés: Atmosphère, Expérience, Aménagement culturel, Culture du rire, Architecture éphémère, Performance, Urbanisation performative, Art relationnel.

Keywords: Atmosphere, Experience, Cultural Planning, Culture of Laughter, Instant Architecture, Performance; Performative Urban Design, Relational Art.

\section{AUTHORS}

\section{HANS KIIB}

Architect, Ph.D., Professor at Aalborg University in Denmark. He lectures and conducts research within urban design, architecture and installations in urban spaces; His latest books are related to architecture, infrastructure, urban spaces and cultural projects, that can enhance a vibrant city life and a catalyze a sustain social development in urban transformation. Hans Kiib is former Chairman of the Study Board for the educational program Architecture \& Design as well as for Art \& Technology at Aalborg University and has participated in creating these educations. Contact: kiib@create.aau.dk 


\section{GITTE MARLING}

Architect, Ph.D., Professor at Aalborg University. She lectures and and conducts research within architecture, urban life and urban space design. She has developed the 'Urban Songline' methodology used for analyses of the relation between citizens' lifestyles, their aesthetic preferences and their particular use of places in the city. Gitte Marling has a particular interest in the design of urban experiences and learning environments. Gitte Marling is former the head of the Ph.D. program, Media, Architecture and Design (MAD) at Aalborg University.

Contact: gitte.marling@gmail.com

\section{LINE MARIE BRUUN JESPERSEN}

Art historian, Assistant Professor, Ph.D. at Aalborg University. Line Marie Bruun Jespersen's research focus on art and the public sphere and public space. In the PhD dissertation "Urbane Installationer" (Urban Installations) from 2011 the meeting between urban spaces, contemporary art and the public/urban life was analyzed in order to describe the potential of art as place making and for generating socially inclusive public spaces. Contemporary approaches to site specificity in art and design and the role of art in local and regional development are central themes in Line Marie Bruun Jespersen's current research.

Contact: linebruun@hum.aau.dk 